ISSN: 2302-8556

E-Jurnal Akuntansi Universitas Udayana

Vol.24.3.September (2018):2333-2359

DOI: https://doi.org/10.24843/EJA.2018.v24.i03.p26

\title{
Pengaruh Corporate Social Responsibility Pada Manajemen Laba
}

\author{
Ni Luh Nia Ardiani ${ }^{1}$ \\ I Putu Sudana ${ }^{2}$
}

${ }^{1}$ Fakultas Ekonomi dan Bisnis Universitas Udayana (Unud), Bali, Indonesia
e-mail: nia.ardiani1603@ gmail.com / telp: +62 89611060586
${ }^{2}$ Fakultas Ekonomi dan Bisnis Universitas Udayana (Unud), Bali, Indonesia

\begin{abstract}
ABSTRAK
Tujuan penelitian ini adalah untuk mengetahui bagaimana pengaruh corporate social responsibility pada manajemen laba dengan good corporate governance sebagai variabel moderasi pada perusahaan high profile yang terdaftar di Bursa Efek Indonesia tahun 2014-2016. Sampel sebanyak 33 amatan yang diperoleh dengan metode purposive sampling. Metode pengumpulan data menggunakan metode dokumentasi. Teknik analisis data adalah analisis regresi moderasi. Penelitian ini menyimpulkan bahwa corporate social responsibility berpengaruh negatif pada manajemen laba, kepemilikan institusional dan komite audit memoderasi pengaruh corporate social responsibility pada manajemen laba. Kepemilikan manajerial tidak memoderasi pengaruh corporate social responsibility pada manajemen laba. Teori biaya politik menyatakan biaya politis yang tinggi akan cenderung memberikan peluang untuk melakukan manajemen laba. Hasil penelitian ini tidak sejalan dengan teori biaya politis tersebut. Hasil penelitian ini memberikan argumentasi bahwa pengungkapan corporate social responsibility yang luas, tidak selalu diikuti dengan praktik manajemen laba.
\end{abstract}

Kata kunci: corporate social responsibility, manajemen laba, kepemilikan institusional, kepemilikan manajerial, komite audit

\begin{abstract}
This study aims to determine the effect of CSR on earnings management with good corporate governance as a moderating variable in high profile companies listed on the Indonesia Stock Exchange in year 20142016. Sampel of 33 observation is obtained with purposive sampling method. Data collection method using documentation method. Data are analyzed is moderation regression analysis. This study concludes that CSR has a negative effect on earnings management, institutional ownership and audit committee moderate the effect of CSR on earnings management. Managerial ownership doesn't moderate the effect of CSR on earnings management. Political cost theory states that high political costs will tend to provide opportunities for earnings management. The results of this study aren't agree with political cost theory. The results of this study provide an argument that broad disclosure of CSR isn't always followed by earnings management practices.
\end{abstract}

Keyword: CSR, earning management, institusional ownership, managerial ownership, audit committee 
Ni Luh Nia Ardiani dan I Putu Sudana. Pengaruh...

\section{PENDAHULUAN}

Perseroan yang kegiatan usahanya dibidang dan/atau berkaitan dengan sumber daya alam wajib melaksanakan tanggung jawab sosial dan lingkungan. Hal ini diatur dalam Undang-Undang Republik Indonesia Nomor 40 Tahun 2007 tentang Perseroan Terbatas. Prior et al. (2007) mendefinisikan tanggung jawab sosial atau corporate social responsibility sebagai serangkaian kegiatan untuk mengembangkan hubungan dengan para pemangku kepentingan perusahaan dan aktivitas lingkungannya. Dampak sosial yang ditimbulkan oleh perusahaan tergantung pada jenis perusahaan.

Perusahaan yang memiliki tingkat sesitifitas yang tinggi terhadap lingkungan disebut perusahaan high profile, sedangkan perusahaan yang memiliki tingkat sensitifitas yang rendah terhadap lingkungan disebut perusahaan low profile. Pengungkapan corporate social responsibility bertujuan agar perusahaan mendapat citra yang baik di mata masyarakat. Namun, pengungkapan corporate social responsibility ini digunakan sebagai tameng untuk menutupi tindakan manajemen laba

yang dilakukan manajemen. Beberapa riset menemukan bahwa corporate social responsibility digunakan oleh manajemen sebagai tameng untuk menutupi praktik manajemen laba untuk menjaga hubungan dengan stakeholders, yaitu penelitian yang dilakukan oleh Suryani dan Herianti (2015), Terzaghi (2012), Yateno dan Sari (2016), Rahmawati dan Dianita (2011), dan Kusuma dan Syafruddin (2014).

Political cost hyphotesis yang dikemukakan oleh Watts dan Zimmerman (1986) dalam Haryanto dan Lina (2017) mengatakan bahwa manajemen laba dipakai pihak 
ISSN: 2302-8556

manajemen untuk mengurangi biaya politik. Political cost hyphotesis mengatakan apabila perusahaan mengeluarkan biaya dalam jumlah yang besar untuk kepentingan politik, maka perusahaan tersebut akan cenderung menggunakan metode akuntansi yang dapat membuat pelaporan laba pada periode berjalan lebih rendah (Sidartha dan Erawati, 2017). Tindakan manajemen laba yang dilakukan manajemen dikarenakan perusahaan mendapat tekanan biaya politik dari pemerintah dalam hal tanggung jawab sosial. Pemerintah mewajibkan perusahaan untuk mengungkapkan laporan pelaksanaan tanggung jawab sosial dan lingkungan dalam laporan tahunan yang tertera pada Pasal 66 ayat (2) UU RI No. 40 Tahun 2007 tentang Perseroan Terbatas.

Penelitian sebelumnya yang dilakukan oleh Gargouri et al. (2010), Suryani dan Herianti (2015), dan Yip et al. (2011) menemukan hasil bahwa corporate social responsibility berpengaruh positif pada manajemen laba, sedangkan hasil penelitian yang berbeda dilakukan oleh Kim et al. (2012) dan Ratmono, dkk. (2014) menemukan hasil bahwa corporate social responsibility berpengaruh negatif pada manajemen laba. Hasil penelitian tersebut memperlihatkan bahwa terdapat inkonsistensi dari penelitian sebelumnya. Pendekatan kontijensi menyatakan bahwa harus dikembangkan suatu variabel lain untuk menjawab hasil penelitian yang berbeda sebelumnya (Sari dan Putri, 2016). Pendekatan kontijensi memberikan peluang kepada variabel-variabel lain yang bertindak sebagai variabel moderating atau intervening (Ayuni dan Erawati, 2018). Variabel moderasi yang digunakan dalam penelitian ini adalah good corporate governance. 
Ni Luh Nia Ardiani dan I Putu Sudana. Pengaruh...

Pemilihan variabel Good Corporate Governance (GCG) didasari pada teori agensi (agency theory) yang menyatakan bahwa masalah ketidakselarasan kepentingan antara principal dan agent dapat diatasi melalui pengelolaan perusahaan yang baik (Midiastuty dan Machfordz, 2003). Agustia (2013) menyatakan bahwa perilaku manajemen laba yang dilakukan oleh manajemen dapat diminimalisir dengan menerapkan good corporate governance (GCG). Menurut Komite Nasional Kebijakan Governance (2006) corporate governance merupakan suatu konsep yang berupaya untuk meningkatkan kinerja perusahaan melalui monitoring aktivitas manajemen untuk menjamin akuntabilitas, transparansi, responsibilitas, indepedensi, kewajaran, dan kesetaraan perusahaan dimata stakeholders. Tujuan diterapkannya good corporate governance adalah mendorong timbulnya kesadaran dan tanggung jawab sosial perusahaan terhadap masyarakat dan kelestarian lingkungan terutama disekitar perusahaan.

Jensen dan Meckling (1976) mengungkapkan bahwa hubungan principal-agent dapat memunculkan agency problem dalam perusahaan. Hubungan keagenan yang terjadi seperti itu akan dapat menimbulkan reputasi perusahaan yang tidak baik, sehingga perusahaan tidak memiliki dukungan dalam berbisnis yang akan dapat menghentikan kegiatan operasi perusahaan (Chrisdianto, 2013). Corporate governance diperlukan dalam mengurangi agency problem, sehingga tercipta keselarasan kepentingan antara pemilik perusahaan dan manajer (Triwahyuningtias dan Muharam, 2012). Mekanisme corporate governance dapat memberikan nilai lebih bagi semua 
ISSN: 2302-8556

E-Jurnal Akuntansi Universitas Udayana

Vol.24.3.September (2018):2333-2359

pihak yang memiliki kepentingan, sehingga tidak terjadi konflik antara pihak agent dan principal atau untuk mengurangi agency problem yang dalam jangka panjang dapat menimbulkan indikasi kebangkrutan (Hanafi dan Breliastiti, 2016).

Firdausya, dkk. (2013) menyatakan bahwa variabel corporate governance dapat diukur dengan menggunakan mekanisme. Mekanisme dalam penelitian ini adalah kepemilikan institusional, kepemilikan manajerial, dan komite audit yang termasuk dalam organ perusahaan. Penggunaan mekanisme tersebut dikarenakan organ perusahaan tersebut dapat menjalankan fungsinya sesuai dengan ketentuan yang berlaku atas dasar prinsip bahwa masing-masing organ mempunyai independensi dalam melaksanakan tugas, fungsi, dan tanggung jawabnya semata-mata untuk kepentingan perusahaan (Komite Nasional Kebijakan Governance, 2006). Selain itu, alasan penggunaan mekanisme tersebut karena merupakan mekanisme eksternal dan internal perusahaan. Kepemilikan institusional termasuk dalam mekanisme eksternal, sedangkan kepemilikan manajerial dan komite audit merupakan mekanisme internal perusahaan.

Kepemilikan institusional mempunyai peran untuk mengendalikan pihak manajemen dengan cara memonitoring secara efektif, sehingga akan dapat menurunkan tingkat manajemen laba (Hidayanti dan Paramita, 2014). Beberapa riset yang dilakukan oleh Sihwahjoeni (2015), Widyastuti (2009) dan Sukasih dan Sugiyanto (2017) menyatakan bahwa kepemilikan institusional dapat menjadi pengendalian dalam mendorong peningkatan pengawasan yang lebih optimal dan efektif terhadap kebijakan manajemen sehingga dapat mengurangi manajemen laba. 
Ni Luh Nia Ardiani dan I Putu Sudana. Pengaruh...

Semakin besar jumlah kepemilikan institusional, maka semakin besar dapat membatasi praktik manajemen laba.

Kepemilikan saham yang dimiliki pihak manajemen dapat membantu dalam menyelaraskan kepentingan antara pemegang saham dan manajer, dikarenakan manajer disini selaku pengelola perusahaan sekaligus pemilik perusahaan. Penelitian yang dilakukan Kouki et al. (2011), Yang et al. (2009), dan Oktovianti dan Agustia (2012) menyatakan ketika pihak manajemen yang memiliki jumlah kepemilikan yang besar, maka akan dapat menurunkan praktik manajemen laba. Hal ini dikarenakan ketika saat manajemen memiliki saham perusahaan seperti pemegang saham umumnya, maka manajemen akan bertindak sama seperti pemegang saham umumnya.

Komite audit memiliki tanggung jawab untuk mengawasi laporan keuangan, mengawasi audit eksternal, dan mengamati sistem pengendalian internal (termasuk audit internal), sehingga dapat mengurangi sifat opportunistic manajemen yang melakukan manajemen laba (Sochib, 2015). Beberapa riset yang dilakukan oleh Lin et al. (2006), Alves (2011), dan Nasution dan Setiawan (2007) menyatakan bahwa adanya komite audit dalam perusahaan mampu mengurangi praktik manajemen laba dikarenakan terdapat pengawasan yang lebih ketat untuk mengawasi perilaku manajemen dalam perusahaan.

Berdasarkan uraian diatas, maka rumusan masalah yang diteliti, yaitu 1). Apakah corporate social responsibility berpengaruh pada manajemen laba?, 2). Apakah proporsi kepemilikan institusional dapat memoderasi pengaruh corporate social responsibility pada manajemen laba?, 3). Apakah kepemilikan manajerial dapat 
ISSN: 2302-8556

E-Jurnal Akuntansi Universitas Udayana

Vol.24.3.September (2018):2333-2359

memoderasi pengaruh corporate social responsibility pada manajemen laba?, 4). Apakah proporsi komite audit dapat memoderasi pengaruh corporate social responsibility pada manajemen laba?.

Kegunaan teoritis penelitian ini adalah untuk memberikan kontribusi untuk peneliti selanjutnya mengenai topik ini. Memberikan tambahan temuan empiris mengenai teori yang mendasari hubungan antar variabel dan memberikan bukti empiris mengenai pengaruh corporate social responsibility pada manajemen laba dengan good corporate governance sebagai variabel moderasi. Kegunaan praktis penelitian ini adalah dapat dijadikan sumber informasi dan masukan kepada perubahan mengenai pentingnya mempersiapkan biaya untuk melakukan aktivitas corporate social responsibility dan pentingnya penerapan good corporate governance didalam perusahaan untuk dapat meminimalisir praktik manajemen laba.

Hipotesis biaya politik (political cost hyphotesis) menyatakan bahwa biaya politis yang tinggi akan cenderung memberikan peluang untuk melakukan praktik manajemen laba. Semakin tinggi perusahaan, maka semakin tinggi pula tekanan politik yang dialami perusahaan tersebut. Biaya politik ini disebabkan karena adanya regulasi dari pemerintah yang mewajibkan perusahaan mengungkapkan laporan tanggung jawab sosial dan lingkungan dalam laporan tahunannya. Biaya politik tersebut mendorong adanya peluang untuk melakukan praktik manajemen laba, sehingga corporate social responsibility digunakan untuk menutupi tindakan tersebut. Penelitian empiris yang dilakukan oleh Suryani dan Herianti (2015), Gargouri et al. (2010), Yip 
Ni Luh Nia Ardiani dan I Putu Sudana. Pengaruh...

et al. (2011) menemukan bahwa corporate social responsibility berpengaruh positif pada manajemen laba. Jadi diduga corporate social responsibility berpengaruh postif pada manajemen laba.

$\mathrm{H}_{1}$ : Corporate social responsibility berpengaruh positif pada manajemen laba.

Gray et al. (1995) menyatakan bahwa teori legitimasi merupakan suatu kondisi atau status yang diterima ketika sistem nilai perusahaan selaras dengan sistem nilai sosial yang lebih besar dan perusahaan merupakan bagian dari sistem sosial tersebut. Dengan kata lain, teori legitimasi merupakan teori yang menjelaskan hubungan antara perusahaan dengan masyarakat. Perusahaan membutuhkan dukungan masyarakat demi kelangsungan hidup perusahaan. Semakin banyak informasi corporate social responsibility yang diungkapkan perusahaan, maka semakin tinggi tingkat legitimasi perusahaan dimata masyarakat. Hal ini dikarenakan adanya corporate social responsibility yang diungkapkan perusahaan menandakan perusahaan tersebut sudah memiliki tanggung jawab sosialnya.

Teori agensi menurut Jensen dan Meckling (1976) adalah teori yang menggambarkan hubungan antara agent dengan principal, berupa pemberian wewenang kepada agent untuk membuat keputusan yang terbaik, sedangkan agent melakukan jasa untuk dan atas nama principal. Adanya hubungan agent dengan principal ini akan dapat menimbulkan konflik keagenan yang disebut agency conflict. Agency conflict ini dapat diatasi dengan pengelolaan perusahaan yang baik. Terdapat empat mekanisme corporate governance yang dapat digunakan untuk mengatasi 
ISSN: 2302-8556

E-Jurnal Akuntansi Universitas Udayana

Vol.24.3.September (2018):2333-2359

konflik keagenan, yaitu meningkatkan kepemilikan manajerial, meningkatkan kepemilikan institusional, komisaris independen, dan komite audit (Rachmawati dan Triatmoko, 2007).

Teori agensi menyatakan bahwa perusahaan yang memiliki fungsi pengelolaan dan fungsi kepemilikan secara terpisah cenderung akan rentan terhadap konflik keagenan. Keberadaan investor institusional diyakini mampu untuk menjadi mekanisme dalam memonitoring pihak manajemen secara efektif. Tingkat kepemilikan institusional yang tinggi akan dapat menurunkan tingkat maajemen laba. Penelitian empiris yang dilakukan oleh Cornett et al. (2006), Midiastuty dan Machfordz (2003), dan Jiambalvo (1996) menemukan bahwa kepemilikan institusional dapat mengurangi tindakan oportunistik manajemen. Jadi diduga kepemilikan institusional dapat memoderasi pengaruh corporate social responsibility pada maanjemen laba.

$\mathrm{H}_{2}$ : Kepemilikan institusional memperlemah pengaruh corporate social responsibility pada manajemen laba.

Jensen dan Meckling (1976) mengungkapkan ketika kepemilikan saham oleh manajemen rendah, maka ada kecenderungan terjadi perilaku oportunistik manajemen yang meningkat. Adanya kepemilikan manajerial didalam perusahaan mendorong manajemen untuk bekerja secara maksimal dan berhati-hati karena manajemen akan ikut menanggung risiko akibat dari tindakan pengambilan keputusan manajemen. Penelitian empiris yang dilakukan oleh Midiastuty dan Machfordz (2003) dan Ujiyantho dan Pramuka (2007) menemukan bahwa kepemilikan maanjerial dapat 
Ni Luh Nia Ardiani dan I Putu Sudana. Pengaruh...

mengurangi konflik antara agent dengan principal. Jadi diduga kepemilikan manajerial dapat memoderasi pengaruh corporate social responsibility pada manajemen laba.

$\mathrm{H}_{3}$ : Kepemilikan manajerial memperlemah pengaruh corporate social responsibility pada manajemen laba.

Teori keagenan juga menyatakan bahwa adanya komite audit akan memberikan pengawasan yang lebih ketat terhadap manajemen. Peran komite audit adalah mengawasi dan mengontrol pihak manajemen (agent), sehingga manajemen merasa diawasi dan akan sulit bertindak dalam menguntungkan dirinya sendiri dan tidak akan merugikan pemegang saham (principal) (Prastiti dan Meiranto, 2013). Penelitian empiris yang dilakukan oleh Anggraeni dan Hadiprajitno (2013) dan Xie et al. (2003) menemukan bahwa adanya komite audit mampu meminimalisir manajemen laba. Jadi diduga komite audit dapat memoderasi pengaruh corporate social responsibility pada manajemen laba.

$\mathrm{H}_{4}$ : Komite audit memperlemah pengaruh corporate social responsibility pada manajemen laba.

\section{METODE PENELITIAN}

Penelitian ini menggunakan pendekatan kuantitatif bersifat asosiatif. Lokasi penelitian ini dilakukan pada perusahaan high profile yang terdaftar di Bursa Efek Indonesia (BEI) pada tahun 2014-2016, dengan cara mengakses website resmi dari BEI dan situs perusahaan masing-masing. Objek dari penelitian ini adalah corporate social responsibility. Penelitian ini menggunakan manajemen laba sebagai variabel terikat, sedangkan variabel bebas yang digunakan, yaitu corporate social responsibility serta 
ISSN: 2302-8556

E-Jurnal Akuntansi Universitas Udayana

Vol.24.3.September (2018):2333-2359

variabel moderasi yang digunakan adalah good corporate governance. Desain penelitian ini ditunjukkan pada Gambar 1.

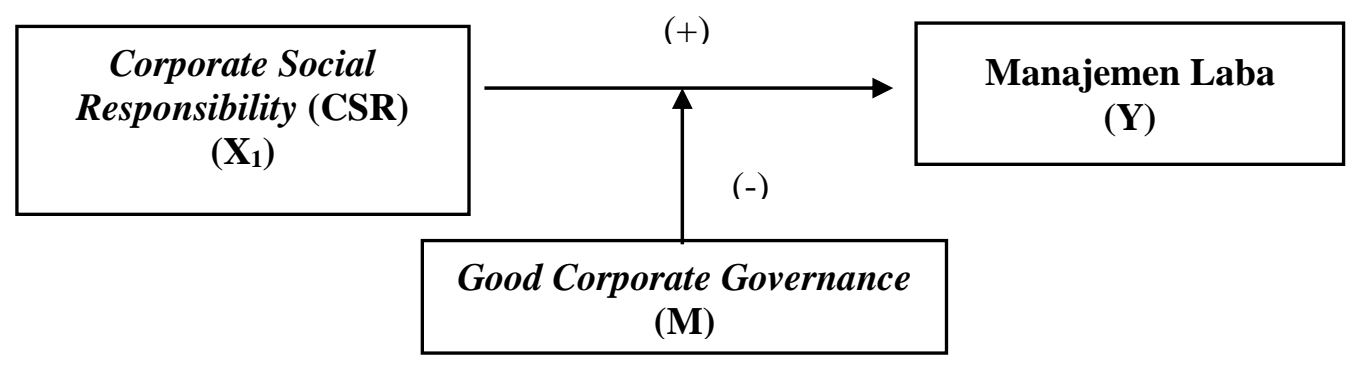

Gambar 1 menunjukkan bahwa corporate social responsibility berpengaruh pada manajemen dengan memiliki arah yang positif, yang berarti corporate social responsibility berpengaruh positif pada manajemen laba dengan good corporate governance sebagai variabel moderasi yang memiliki arah negatif, yang berarti variabel good corporate governance memperlemah pengaruh corporate social responsibility pada manajemen laba.

Data dikumpulkan menggunakan metode dokumentasi, yaitu suatu cara pengumpulan data secara tidak langsung memberikan data kepada pengumpul data yang diperoleh dari dokumen-dokumen yang ada (Sugiyono, 2016). Data diukumpulkan dengan cara mengamati, mencatat, dan mempelajari laporan tahunan dan laporan berkelanjutan (sustainability report) mengenai data yang berkaitan dengan penelitian yang dilakukan. Populasi dalam penelitian ini adalah perusahaan high profile yang terdaftar di BEI pada tahun 2014-2016, yaitu sebanyak 183 perusahaan. Sampel ditentukan dengan metode purposive sampling, yakni penentuan sampel dengan 
Ni Luh Nia Ardiani dan I Putu Sudana. Pengaruh...

kriteria tertentu. Jumlah sampel yang memenuhi kriteria berdasarkan teknik purposive sampling sebanyak 11 perusahaan dengan 3 tahun amatan menjadi 33 sampel yang ditunjukkan pada Tabel 1.

\section{Tabel 1.}

Jumlah Sampel Perusahaan

\begin{tabular}{lll}
\hline & Kriteria & Jumlah \\
\hline Perusahaan & high profile yang terdaftar di Bursa Efek Indonesia (BEI) & $\mathbf{1 8 3}$ \\
\hline Perusahaan high profile yang tidak menerbitkan laporan & \\
keberlanjutan (sustainability report) dengan indikator GRI selama & $(168)$ \\
tahun 2014, 2015, dan 2016 pada situs perusahaan. & \\
Perusahaan yang dalam laporan tahunan (annual report) tidak & \\
menampilkan informasi mengenai kepemilikan institusional, & $(4)$ \\
kepemilikan manajerial, dan komite audit. & $\mathbf{1 1}$ \\
\hline Sampel yang digunakan & $\mathbf{3 3}$ \\
\hline Jumlah amatan penelitian (2014-2016) &
\end{tabular}

Manajemen laba adalah pilihan kebijakan akuntansi oleh manajer sehingga dapat mencapai beberapa tujuan yang spesifik (Scott,2006 dalam Ermayanti, 2016). Manajemen laba dalam penelitian ini diukur menggunakan proksi discretionary accrual (DAC) dari model Jones yang dimodifikasi (Modified Jones Method). Berikut langkah-langkah perhitungan untuk mencari nilai DAC menurut Agustia (2013) adalah sebagai berikut:

a) Menghitung total akrual

$$
\mathrm{TA}_{\mathrm{it}}=\mathrm{N}_{\mathrm{it}}-\mathrm{CFO}_{\mathrm{it}}
$$

Keterangan:

$\mathrm{TA}_{\mathrm{it}}$ :Total akrual perusahaan i pada periode waktu $\mathrm{t}$ $\mathrm{N}_{\mathrm{it}} \quad$ :Laba bersih perusahaan i pada periode waktu $\mathrm{t}$

$\mathrm{CFO}_{\text {it }}$ :Aliran kas dari aktivitas operasi perusahaan i pada periode waktu $\mathrm{t}$

b) Menghitung Non Discretionary Accruals 
$\left.\mathrm{NDA}_{i t}=\beta_{1}\left(1 / \mathrm{A}_{\mathrm{it}-1}\right)+\beta_{2}\left(\left(\Delta \mathrm{REV}_{\mathrm{it}}-\Delta \mathrm{REC}_{\mathrm{it}}\right) / \mathrm{A}_{\mathrm{it}-1}\right)\right)+\beta_{3}\left(\mathrm{PPE}_{\mathrm{it}} / \mathrm{A}_{\mathrm{it}-1}\right)$

Keterangan:

NDA $_{i t}:$ Non discretionary accruals perusahaan i pada periode $t$

$\mathrm{A}_{\mathrm{it}-1} \quad$ : Total aset perusahaan i pada periode waktu t-1

$\triangle \mathrm{REV}_{\mathrm{it}}$ : Perubahan pendapatan perusahaan i pada periode waktu $\mathrm{t}$

$\triangle \mathrm{REC}_{\text {it }}$ : Perubahan piutang perusahaan i pada periode waktu $\mathrm{t}$

$\mathrm{PPE}_{\text {it }} \quad$ : Aset tetap perusahaan i pada periode waktu $\mathrm{t}$

$\beta \quad$ : Koefisien regresi

c) Menghitung Discretionary Accruals (DA)

$$
\mathrm{DA}_{\mathrm{it}}=\mathrm{TA}_{\mathrm{it}}-\mathrm{NDA}_{\mathrm{it}}
$$

\section{Keterangan:}

$\mathrm{DA}_{\text {it }}$ : Discretionary accruals perusahaan i pada periode waktu $\mathrm{t}$

$\mathrm{TA}_{\text {it }}$ : Total akrual perusahaan i pada periode waktu $\mathrm{t}$

Corporate social responsibility pada penelitian ini menggunakan Corporate

Social Responsibility Disclosure yang diproksikan dengan Corporate Social Responsibility Disclosure Index (CSRDI). Jumlah item dalam CSRDI dapat dihitung berdasarkan pedoman kategori yang dikeluarkan oleh GRI G4, yang terbagi menjadi enam kategori. Kategori tersebut terdiri dari kategori ekonomi, kategori lingkungan, dan kategori sosial yang terbagi lagi menjadi sub-kategori praktik ketenagakerjaan dan kenyamanan bekerja, hak asasi manusia, masyarakat, dan tanggung jawab atas produk. Rumus yang digunakan untuk mengukur indeks dimensi pengungkapan CSR menurut Terzaghi (2012) adalah sebagai berikut:

$$
\text { CSRDI }=\frac{\text { Jumlah item pengungkapan oleh perusahaan }}{\text { Jumlah pengungkapan yang seharusnya diungkapkan oleh GRI }}
$$

Forum for Corporate Governance Indonesia (FCGI) mengambil dari Cadbury Comitte of United Kingdom, corporate governance dapat didefinisikan sebagai 
Ni Luh Nia Ardiani dan I Putu Sudana. Pengaruh...

seperangkat peraturan yang mengatur hubungan antara pemegang saham, manajer, kreditur, pemerintah, karyawan, serta para pemegang kepentingan internal dan eksternal yang lainnya yang berkaitan dengan hak dan kewajiban mereka atau dengan kata lain suatu sistem yang mengarahkan dan mengendalikan perusahaan. Good corporate governance dalam penelitian ini diproksikan dengan kepemilikan institusional, kepemilikan manajerial, dan komite audit.

Kepemilikan institusional adalah kepemilikan saham oleh institusi berbadan hukum, institusi keuangan, institusi luar negeri, dana perwakilan serta institusi lainnya. Dalam kepemilikan ini, pengukuran variabel menggunakan proporsi kepemilikan saham institusional, yaitu rasio antar kepemilikan saham institusional terhadap total saham beredar (Oh et al. 2011). Rumus untuk perhitungan kepemilikan institusional menurut Oh et al. (2011) adalah sebagai berikut:

$$
\mathrm{KI}=\frac{\text { Jumlah saham yang dimiliki institusi }}{\text { Jumlah saham yang beredar }} \times 100 \%
$$

Kepemilikan manajerial adalah situasi dimana manajer memiliki saham perusahaan atau dengan kata lain manajer tersebut sekaligus pemilik atau pemegang saham (Faizal, 2004). Pengukuran pengaruh kepemilikan manajemen terhadap pengaruh pengungkapan lingkungan menggunakan persentase saham yang dimiliki manajemen. Rumus untuk perhitungan kepemilikan manajerial menurut Subiantoro dan Mildawati (2015) adalah sebagai berikut:

$$
\mathrm{KM}=\frac{\text { Jumlah saham yang dimiliki pihak manajemen }}{\text { Jumlah saham yang beredar }} \times 100 \%
$$


ISSN: 2302-8556

E-Jurnal Akuntansi Universitas Udayana

Vol.24.3.September (2018):2333-2359

Komite audit menurut Keputusan Ketua Bapepam Nomor Kep-643/BL/2012 adalah komite yang dibentuk oleh dewan komisaris untuk melakukan tugas dan fungsinya. Komite audit ini memiliki tanggung jawab pengawasan untuk pelaporan luar perusahaan, pemonitoran risiko, dan proses pengendalian, dan baik fungsi audit internal dan eksternal (Tunggal, 2013 dalam Taco dan Ilat, 2016). Komite audit diukur dengan menghitung jumlah komite audit diluar komisaris independen dibagi dengan jumlah seluruh komite perusahaan. Rumus untuk perhitungan komite audit menurut Swingly dan Sukartha (2015) adalah sebagai berikut:

$$
\mathrm{KA}=\frac{\text { Jumlah anggota komite audit diluar komisaris independen }}{\text { Total komite audit }} \times 100 \% \ldots . .(7)
$$

Teknik analisis data yang digunakan dalam penelitian ini adalah analisis regresi moderasi atau moderated regression analysis (MRA). Adapun persamaan dari model analisis regresi dalam penelitian ini adalah sebagai berikut:

$$
Y=\beta_{1} X_{1}+\beta_{2} M_{1}+\beta_{3} X_{1} * M_{1}+\beta_{4} M_{2}+\beta_{5} X_{1} * M_{2}+\beta 6 M_{3}+\beta_{7} X_{1} * M_{3}+\varepsilon
$$

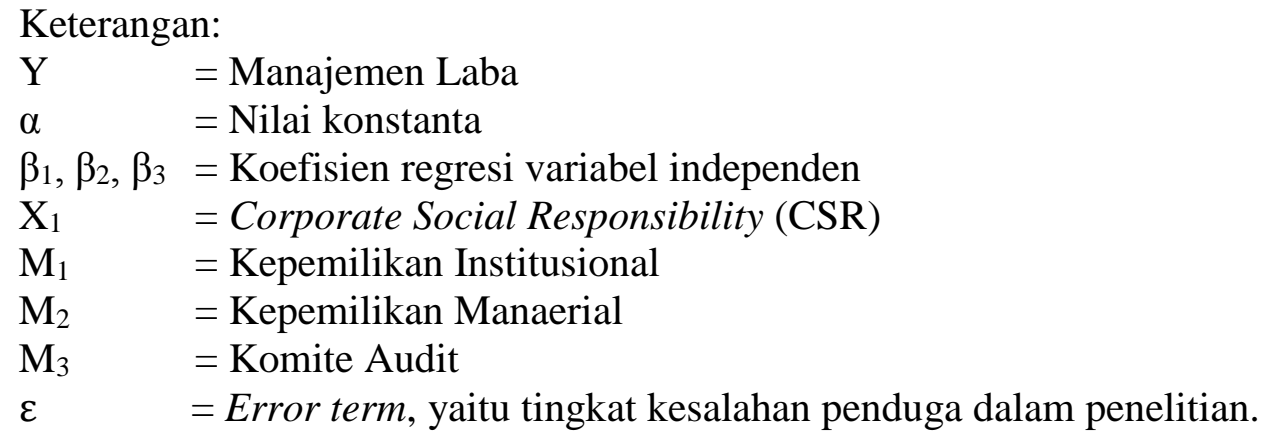


Ni Luh Nia Ardiani dan I Putu Sudana. Pengaruh...

\section{HASIL DAN PEMBAHASAN}

Hasil statistik deskriptif ditampilkan untuk memberikan informasi mengenai karakteristik dari variabel penelitian, yaitu minimum (minimum), maximum (maksimum), mean (rata-rata), dan standard deviation (simpangan baku). Hasil statistik deskriptif dalam penelitian ini disajikan pada Tabel 2.

\section{Tabel 2.}

Hasil Statistik Deskriptif Variabel Penelitian

\begin{tabular}{|c|c|c|c|c|c|c|}
\hline No. & Variabel & $\mathbf{N}$ & Minimum & Maximum & Mean & $\begin{array}{c}\text { Std. } \\
\text { Deviation } \\
\end{array}$ \\
\hline 1. & Manajemen Laba (Y) & 33 & .0782 & .4513 & .224264 & .684116 \\
\hline 2. & $\begin{array}{ll}\text { Corporate } & \text { Social } \\
\text { Responsibility } & \text { (CSR) } \\
\left(\mathrm{X}_{1}\right) & \end{array}$ & 33 & .6207 & 1.8333 & 1.181106 & .2132301 \\
\hline 3. & $\begin{array}{l}\text { Kepemilikan } \\
\text { Institusional }\left(\mathrm{M}_{1}\right)\end{array}$ & 33 & 18.1000 & 99.1700 & 60.060242 & 24.18725 \\
\hline 4. & $\begin{array}{l}\text { Interaksi CSR dengan } \\
\text { Kepemilikan } \\
\text { Institusional }\left(\mathrm{X}_{1} \mathrm{M}_{1}\right)\end{array}$ & 33 & 19.5707 & 119.8612 & 70.371594 & 27.12355 \\
\hline 5. & $\begin{array}{l}\text { Kepemilikan Manajerial } \\
\left(\mathrm{M}_{2}\right)\end{array}$ & 33 & .0007 & .0688 & .016030 & .0158624 \\
\hline 6. & $\begin{array}{l}\text { Interaksi CSR dengan } \\
\text { Kepemilikan Manajerial } \\
\left(\mathrm{X}_{1} \mathrm{M}_{2}\right)\end{array}$ & 33 & .0009 & .0688 & .018433 & .0160171 \\
\hline 7. & Komite Audit $\left(\mathrm{M}_{3}\right)$ & 33 & .6700 & .8000 & .718667 & .0335361 \\
\hline 8. & $\begin{array}{l}\text { Interaksi CSR dengan } \\
\text { Komite Audit }\left(\mathrm{X}_{1} \mathrm{M}_{3}\right)\end{array}$ & 33 & .4159 & 1.3365 & .851638 & .1686301 \\
\hline
\end{tabular}

Setelah ini dilakukan uji asumsi klasik yang terdiri dari uji normalitas, uji autokorelasi, dan uji heteroskedastisitas. Uji normalitas menggunakan uji KolmogorovSmirnov, memiliki nilai Asymp. Sig (2-tailed) sebesar 0,171. Nilai Asymp. Sig (2-tailed) 0,171 yang lebih besar dari $\alpha$ sebesar 0,05 , maka dapat diinterpretasikan bahwa residual dari model telah berdistribusi normal. Uji autokorelasi menggunakan Uji DurbinWatson (DW-test) menunjukkan nilai DW sebesar 2,020 yang lebih besar dari batas 
ISSN: 2302-8556

E-Jurnal Akuntansi Universitas Udayana

Vol.24.3.September (2018):2333-2359

atas (dU), yaitu 1,9906 dan kurang dari (4-dU) sebesar 2,0094, jadi dapat diinterpretasikan bahwa tidak adanya autokorelasi. Hasil uji heteroskedastisitas menunjukkan bahwa seluruh nilai signifikan variabel lebih besar dari $\alpha$, yaitu 0,05 , sehingga dapat disimpulkan bahwa model penelitian ini tidak memiliki gejala heteroskedastisitas.

Analisis regresi moderasi atau moderated regression analysis (MRA) digunakan untuk mengetahui dan menunjukkan apakah kepemilikan institusional, kepemilikan manajerial, dan komite audit sebagai variabel moderasi memperkuat atau memperlemah pengaruh corporate social responsibility pada manajemen laba baik secara simultan dan parsial. Nilai koefisien determinasi (Adjusted R Square) sebesar 0,662 yang memiliki makna bahwa variabel dalam model regresi, yaitu corporate social responsibility dan good corporate governance yang diproksikan dengan kepemilikan institusional, kepemilikan manajerial, dan komite audit dapat menjelaskan variabel manajemen laba sebesar 66,2 persen, sedangkan 33,8 persen dipengaruhi oleh faktor lainnya yang tidak masuk dalam model. Hasil pengujian uji F, menunjukkan nilai signifikansi sebesar 0,000 dengan nilai signifikansi $0,000<0,05$, yang memiliki arti bahwa seluruh variabel mampu menjelaskan manajemen laba pada perusahaan high profile. 
Ni Luh Nia Ardiani dan I Putu Sudana. Pengaruh...

Tabel 3.

\begin{tabular}{|c|c|c|c|c|c|c|}
\hline \multicolumn{7}{|c|}{ Hasil Analisis Regresi Moderasi } \\
\hline \multirow{2}{*}{\multicolumn{2}{|c|}{ Model }} & \multicolumn{2}{|c|}{$\begin{array}{l}\text { Unstandardized } \\
\text { Coefficients }\end{array}$} & \multirow{2}{*}{$\begin{array}{c}\begin{array}{c}\text { Standardized } \\
\text { Coefficients }\end{array} \\
\text { Beta }\end{array}$} & \multirow[b]{2}{*}{$\mathbf{t}$} & \multirow[b]{2}{*}{ Sig. } \\
\hline & & B & $\begin{array}{l}\text { Std. } \\
\text { Error }\end{array}$ & & & \\
\hline \multirow[t]{8}{*}{1} & (Constant) & 3.830 & 1.155 & & 3.316 & .003 \\
\hline & $\mathrm{X}_{1}$ & -3.305 & 1.033 & -10.302 & -3.200 & .004 \\
\hline & $\mathrm{M}_{1}$ & -.010 & .004 & -3.370 & -2.300 & .030 \\
\hline & $\mathrm{X}_{\mathrm{I}} \mathrm{M}_{1}$ & .008 & .004 & 3.030 & 2.074 & .049 \\
\hline & $\mathrm{M}_{2}$ & 9.152 & 8.341 & .2 .122 & 1.097 & .283 \\
\hline & $\mathrm{X}_{1} \mathrm{M}_{2}$ & -6.883 & 7.779 & -1.612 & -.885 & .385 \\
\hline & $\mathrm{X}_{3}$ & -4.857 & 1.631 & -2.381 & -2.978 & .006 \\
\hline & $\mathrm{X}_{1} \mathrm{M}_{3}$ & 4.465 & 1.432 & -11.006 & -3.119 & .005 \\
\hline \multicolumn{2}{|c|}{ F hitung } & 9.956 & & & & \\
\hline \multicolumn{2}{|c|}{ Signifikansi F } & $: \quad .000$ & & & & \\
\hline \multicolumn{2}{|c|}{ R Square } & $: .736$ & & & & \\
\hline \multicolumn{2}{|c|}{ Adjusted R Square } & .662 & & & & \\
\hline
\end{tabular}

Hipotesis pertama $\left(\mathrm{H}_{1}\right)$ menyatakan bahwa corporate social responsibility berpengaruh positif pada manajemen laba. Tabel 3 menunjukkan koefisien corporate social responsibility sebesar -3,305 yang memiliki arah negatif dengan nilai signifikan sebesar $0,004<0,05$, maka $\mathrm{H}_{1}$ ditolak. Hasil penelitian ini menandakan bahwa variabel corporate social responsibility berpengaruh negatif pada manajemen laba.

Hipotesis kedua $\left(\mathrm{H}_{2}\right)$ menyatakan bahwa kepemilikan institusional memperlemah pengaruh corporate social responsibility pada manajemen laba. Tabel 3 menunjukkan koefisien interaksi corporate social responsibility dengan kepemilikan institusional sebesar 0,008 yang memiliki arah positif dan nilai signifikan sebesar 0,049 $<0,05$, maka $\mathrm{H}_{2}$ ditolak. Hasil penelitian ini menandakan bahwa kepemilikan institusional memoderasi dengan memperkuat pengaruh corporate social responsibility pada manajemen laba. Nilai signifikan variabel kepemilikan isntitusional sebesar 0,030 (signifikan) dan nilai signifikan interaksi corporate social responsibility 
ISSN: 2302-8556

dengan kepemilikan institusional sebesar 0,049 (signifikan). Hal ini menandakan bahwa moderasi ini merupakan tipe moderasi quasi.

Hipotesis ketiga $\left(\mathrm{H}_{3}\right)$ menyatakan bahwa kepemilikan manajerial memperlemah pengaruh corporate social responsibility pada manajemen laba. Tabel 3 menunjukkan koefisien interaksi corporate social responsibility dengan kepemilikan manajerial sebesar -6,883 yang memiliki arah negatif dan nilai signifikan sebesar 0,385 > 0,005, maka $\mathrm{H}_{3}$ ditolak. Hasil penelitian ini menandakan bahwa kepemilikan manajerial tidak memoderasi pengaruh corporate social responsibility pada manajemen laba. Nilai signifikan variabel kepemilikan manajerial sebesar 0,283 (tidak signifikan) dan nilai signifikan interaksi corporate social responsibility dengan kepemilikan manajerial sebesar 0,385 (tidak signifikan). Hal ini menandakan bahwa moderasi ini merupkan tipe moderasi homologizer.

Hipotesis keempat $\left(\mathrm{H}_{4}\right)$ menyatakan bahwa komite audit memperlemah pengaruh corporate social responsibility pada manajemen laba. Tabel 3 menunjukkan koefisien interaksi corporate social responsibility dengan komite audit sebesar 4,465 yang memiliki arah positif dan nilai signifikan sebesar $0,005<0,05$, maka $\mathrm{H}_{4}$ ditolak. Hasil penelitian ini menandakan bahwa komite audit memoderasi dengan memperkuat pengaruh corporate social responsibility pada manajemen laba. Nilai signifikan variabel komite audit sebesar 0,006 (signifikan) dan nilai signifikan interaksi corporate social responsibility dengan komite audit sebesar 0,005 (signifikan). Hal ini menandakan bahwa moderasi ini merupkan tipe moderasi quasi. 
Ni Luh Nia Ardiani dan I Putu Sudana. Pengaruh...

Corporate social responsibility berpengaruh negatif pada manajemen laba memiliki arti bahwa semakin tinggi intensitas corporate social responsibility, maka akan dapat menurunkan manajemen laba. Hipotesis biaya politik menyatakan bahwa biaya politis yang tinggi akan cenderung memberikan peluang untuk melakukan manajemen laba. Hasil penelitian ini tidak membuktikan hipotesis biaya politik tersebut. Hal ini menunjukkan bahwa perusahaan yang mengungkapkan corporate social responsibility banyak atau sedikit tidak semata-mata untuk tujuan legitimatif, yaitu manajemen laba. Perusahaan yang sudah mengungkapkan corporate social responsibility berarti perusahaan tersebut sudah memiliki tanggung jawab sosial. Hasil penelitian ini sejalan dengan penelitian yang dilakukan oleh Ricardo dan Faisal (2015), Chih et al. (2008), dan Evadewi dan Meiranto (2014) yang menemukan hasil corporate social responsibility berpengaruh negatif signifikan pada maanjemen laba.

Kepemilikan institusional memperkuat hubungan corporate social responsibility pada manajemen laba memiliki arti bahwa kepemilikan institusional yang tinggi akan dapat menurunkan kembali manajemen laba yang dipengaruhi oleh corporate social responsibility. Teori agensi menyatakan bahwa perusahaan yang memiliki fungsi pengelolaan dan fungsi kepemilikan saham secara terpisah akan dapat menimbulkan agency conflict. Keberadaan investor institusional diyakini mampu untuk memonitoring manajemen. Hasil penelitian ini sejalan dengan teori tersebut. Hal ini menunjukkan bahwa kepemilikan institusional sudah menjadi mekanisme yang efektif dalam memonitorng manajemen, sehingga akan dapat menurunkan tingkat manajemen 
ISSN: 2302-8556

E-Jurnal Akuntansi Universitas Udayana

Vol.24.3.September (2018):2333-2359

laba. Hasil penelitian ini sejalan dengan penelitian yang dilakukan oleh Widyastuti (2009), Sihwahjoeni (2015), dan Midiastuty dan Machfordz (2003) yang menyatakan bahwa kepemilikan institusional mampu mengurangi tindakan manajemen laba.

Kepemilikan manajerial tidak memoderasi corporate social responsibility pada manajemen laba memiliki arti bahwa kepemilikan manajerial yang tinggi atau rendah tidak mampu mempengaruhi praktik manajemen laba. Teori agensi menyatakan dengan kepemilikan saham yang tinggi mampu untuk memonitoring. Hasil penelitian ini tidak sejalan dengan teori tersebut. Hal ini menunjukkan bahwa adanya kepemilikan manajerial bukan berarti manajemen tidak melakukan manajemen laba. Tidak ada artinya kepemilikan saham oleh manajemen di dalam perusahaan dikarenakan tidak ada pihak yang memonitoring kembali tindakan yang dilakukan pihak manajemen. Hasil penelitian ini sejalan dengan penelitian yang dilakukan oleh Setiawan (2009), Guna dan Herawaty (2010), Anggraeni dan Hadiprajitno (2013), dan Santana dan Wirakusuma (2016) yang berpendapat bahwa kepemilikan manajerial tidak berpengaruh pada manajemen laba.

Komite audit memperkuat hubungan corporate social responsibility pada manajemen laba memiliki arti bahwa semakin banyak jumlah komite audit, maka yang akan dapat menurunkan kembali manajemen laba yang dipengaruhi oleh corporate social responsibility. Teori agensi berpendapat bahwa komite audit memberikan pengawasan yang lebih ketat terhadap manajemen. Hasil penelitian ini sejalan dengan teori tersebut. Hal ini menunjukkan bahwa komite audit yang sudah mengontrol dan 
Ni Luh Nia Ardiani dan I Putu Sudana. Pengaruh...

mengawasi perusahaan dengan efektif akan memperketat pengawasan, sehingga dapat menurunkan praktik manajemen laba. Hasil penelitian ini sejalan dengan penelitian yang dilakukan oleh Setiawan (2009), Tiswiyanti, dkk. (2012), dan Anggraeni dan Hadiprajitno (2013) yang menyatakan bahwa komite audit dapat mengurangi tindakan manajemen laba.

\section{SIMPULAN}

Berdasarkan hasil penelitian yang dilakukan, maka dapat disimpulkan bahwa semakin tinggi intensitas corporate social responsibility, maka akan dapat menurunkan tingkat manajemen laba. Teori biaya politik menyatakan bahwa tekanan biaya politik yang tinggi akan cenderung memberikan peluang untuk melakukan manajemen laba. Hasil penelitian ini tidak sejalan dengan teori tersebut. Perusahaan yang sudah mengungkapkan corporate social responsibility tidak semata-mata untuk tujuan legitimatif saja, melainkan perusahaan tersebut sudah memiliki tanggung jawab sosial.

Kepemilikan institusional yang tinggi akan dapat menurunkan kembali tingkat manajemen laba yang dipengaruhi oleh corporate social responsibility. Kepemilikan manajerial yang tinggi atau rendah tidak mampu mempengaruhi praktik manajemen laba. Teori agensi menyatakan bahwa adanya kepemilikan saham yang tinggi, memiliki tingkat untuk memonitoring. Hasil penelitian kepemilikan institusional sejalan dengan teori tersebut, sedangkan hasil penelitian kepemilikan manajerial tidak sejalan dengan teori agensi. Kepemilikan institusional mampu memonitoring manajemen, sehingga dapat menurunkan manajemen laba. Kepemilikan manajemen tidak efektif untuk 
ISSN: 2302-8556

E-Jurnal Akuntansi Universitas Udayana

Vol.24.3.September (2018):2333-2359

memonitoring karena tidak ada yang memonitor kembali tindakan yang diambil oleh pihak manajemen. Jumlah komite audit yang semakin banyak akan dapat menurunkan kembali tingkat manajemen laba yang dipengaruhi oleh corporate social responsibility. Teori agensi menyatakan bahwa komite audit memberikan pengawas yang efektif terhadap manajemen. Hasil penelitian ini sejalan dengan teori tersebut. Adamya komite audit yang efektif dalam mengontrol perusahaan akan menurunkan tingkat manajemen laba.

Berdasarkan hasil penelitian dan simpulan diatas, maka saran yang dapat diberikan yakni peneliti selanjutnya harus mempertimbangkan pemakaian teori lainnya, seperti teori stakeholders dikarenakan hasil penelitian ini tidak membuktikan teori biaya politik, dimana corporate social responsibility bukan digunakan hanya tujuan legitimatif, dan perusahaan harus mengungkapkan corporate social responsibility yang bergandengan dengan good corporate governance secara berkesinambungan agar dapat menurunkan tingkat manajemen laba.

\section{REFERENSI}

Agustia, D. (2013). Pengaruh Faktor Good Corporate Governance, Free Cash Flow, dan Leverage Terhadap Manajemen Laba. Jurnal Akuntansi Dan Keuangan, 15.

Alves, S. M. G. (2011). The Effect of The Board Structure on Earnings Management : Evidence from Portugal. Journal of Financial Reporting and Accounting, 9(2), 141-160.

Anggraeni, R. M., \& Hadiprajitno, P. B. (2013). Pengaruh Struktur Kepemilikan Manajerial, Ukuran Perusahaan, dan Praktik Corporate Governance Terhadap Manajemen Laba. Diponegoro Journal of Accounting, 2, 1-13.

Chih, H.-L., Shen, C.-H., \& Kang, F.-C. (2008). Corporate Social Responsibility, Investor Protection, and Earnings Management: Some International Evidence. 
Ni Luh Nia Ardiani dan I Putu Sudana. Pengaruh...

Journal of Business Ethics, 79, 179-198.

Chrisdianto, B. (2013). Peran Komite Audit Dalam Good Corporate Governance. Jurnal Akuntansi Aktual, 2, 1-8.

Cornett, M. M., Marcus, A. J., Saunders, A., \& Tehranian, H. (2006). Earnings Management, Corporate Governance, and True Financial Performance. College of Business and Administration, Southern Illinois University, Carbondale.

Evadewi, R., \& Meiranto, W. (2014). Pengaruh Pengungkapan Corporate Social Responsibility Terhadap Earnings Management: a Political Cost Perspective. Diponegoro Journal of Accounting, 03, 1-12.

Gargouri, R. ., Francoeur, C., \& Shabou, R. (2010). The Relationship between Corporate Social Performance and Earnings Management. Canadian Journal of Administrative Sciences / Revue Canadienne Des Sciences de l'Administration.

Gray, R., Kouhy, R., \& Lavers, S. (1995). Corporate Social and Environmental Reporting: A Review of the Literature and a Longitudinal Study of UK Disclosure. Accounting, Auditing \& Accountability Journal, 8(2), 47-77.

Guna, W. I., \& Herawaty, A. (2010). Pengaruh Mekanisme Good Corporate Governance, Independensi Auditor, Kualitas Audit Dan Faktor Lainnya Terhadap Manajemen Laba. Jurnal Bisnis Dan Akuntansi, 12(1), 53-68.

Hidayanti, E., \& Paramita, R. W. . (2014). Pengaruh Good Corporate Governance Terhadap Praktik Manajemen Laba Riil Pada Perusahaan Manufaktur. Jurnal Widya Gama (WIGA), 4(2), 1-16.

Jensen, C., \& Meckling, H. (1976). Theory Of The Firm: Managerial Behavior, Agency Costs and Ownership Structure. Journal of Financial Economics, 3, 305360 .

Jiambalvo, J. (1996). Discussion of Causes and Consequences of Eamings Manipulation : An Analysis of Firms Subject to Enforcement Actions by the SEC. Contemporary Accounting Research, 13(1), 37-47.

Kim, Y., Park, M. S., \& Wier, B. (2012). Is Earnings Quality Associated with Corporate Social Responsibility? The Accounting Review, 87(3), 761-796.

Kouki, M., Elkhaldi, A., Atri, H., \& Soui. (2011). Does Corporate Governance Constrain Earnings Management? Evidence from U . S . Firms. European Journal of Economics, Finance \& Administrative Sciences.

Lin, J. W., Li, J. F., \& Yang, J. S. (2006). The Effect of Audit Committee Performance on Earnings Quality. Managerial Auditing Journal, 21(9), 921-933. 
ISSN: 2302-8556

E-Jurnal Akuntansi Universitas Udayana Vol.24.3.September (2018):2333-2359

Midiastuty, P. P., \& Machfordz, M. (2003). Analisis Hubungan Mekanisme Corporate Governance dan Indikasi Manajemen Laba. Simposium Nasional Akuntansi VI, 176-199.

Nasution, M., \& Setiawan, D. (2007). Pengaruh Corporate Governance Terhadap Manajemen Laba di Industri Perbankan Indonesia. Simposium Nasional Akuntansi X, 1-26.

Oh, W. Y., Chang, Y. K., \& Martynov, A. (2011). The Effect of Ownership Structure on Corporate Social Responsibility: Empirical Evidence from Korea. Journal Business Ethics, 283-297.

Oktovianti, T., \& Agustia, D. (2012). Influence of the Internal Corporate Governance and Leverage Ratio to the Earnings Management. Journal of Basic and Applied Scientific Research, 2(7), 7192-7199.

Prastiti, A., \& Meiranto, W. (2013). Pengaruh Karakteristik Dewan Komisaris dan Komite Audit Terhadap Manajemen Laba. Diponegoro Journal of Accounting, 2, $1-12$.

Prior, D., Surroca, J., \& Tribo, J. . (2007). Earnings Management and Corporate Social Responsibility. Business Economic, 1-42.

Rachmawati, A., \& Triatmoko, H. (2007). Analisis Faktor-Faktor Yang Mempengaruhi Kualitas Laba dan Nilai Perusahaan. Simposium Nasional Akuntansi X, 1-26.

Ratmono, D., Purwanto, A., \& Cahyonowati, N. (2014). Hubungan Tingkat Pengungkapan dan Kinerja Corporate Social Responsibility Serta Manajemen Laba : Pengujian Teori Ekonomi. Jurnal Akuntansi Dan Keuangan, 16(2), 63-73.

Ricardo, D. M., \& Faisal. (2015). Pengaruh Pengungkapan Corporate Social Responsibility Terhadap Praktik Manajemen Laba. Diponegoro Journal of Accounting, 4, 33-42.

Santana, D. K. W., \& Wirakusuma, M. G. (2016). Pengaruh Perencanaan Pajak, Kepemilikan Manajerial dan Ukuran Perusahaan Terhadap Praktek Manajemen Laba. E-Jurnal Ekonomi Dan Bisnis Universitas Udayana, 3, 1555-1583.

Setiawan, T. (2009). Analisis Pengaruh Mekanisme Good Corporate Governance Terhadap Praktek Manajemen Laba Pada Perusahaan Manufaktur Yang Terdaftar Di Bursa Efek Indonesia Periode 2005-2007. Jurnal Akuntansi Kontemporer, 1(2), 99-122.

Sihwahjoeni. (2015). Pengaruh Good Corporate Governance Terhadap Ukuran Perusahaan Dan Dampaknya Pada Manajemen Laba. Jurnal Seminar Nasional Ekonomi Manajemen Dan Akuntansi (SNEMA), 3(8), 663-676. 
Ni Luh Nia Ardiani dan I Putu Sudana. Pengaruh...

Sochib. (2015). Pengaruh Penerapan Good Corporate Governance Terhadap Manajemen Laba Serta Kinerja Keuangan. Jurnal Widya Gama (WIGA), 5(1), 3445.

Subiantoro, O. H., \& Mildawati, T. (2015). Pengaruh Karakteristik Perusahaan Terhadap Pengungkapan Corporate Social Responsibility. Jurnal Ilmu Dan Riset Akuntansi, 4(9).

Sugiyono, P. D. (2016). Metode Penelitian Administrasi Dilengkapi dengan Metode $R \& D$ (Edisi 23). Bandung: Alfabeta.

Sukasih, A., \& Sugiyanto, E. (2017). Pengaruh Struktur Good Corporate Governance dan Kinerja Lingkungan Terhadap Pengungkapan Corporate Social Responsibility. Riset Akuntansi Dan Keuangan Indonesia, 2(2), 121-131.

Suryani, A., \& Herianti, E. V. A. (2015). Pengaruh Pengungkapan Tanggung Jawab Sosial Perusahaan terhadap Koefisen Respon Laba dan Manajemen Laba. Simposium Nasional Akuntansi XVIII. Medan.

Swingly, C., \& Sukartha, I. M. (2015). Pengaruh Karakteristik Eksekutif, Komite Audit, Ukuran Perusahaan, Leverage dan Sales Growth Pada Tax Avoidance. EJurnal Akuntansi Universitas Udayana, 1, 47-62.

Terzaghi, M. T. (2012). Pengaruh Earning Management dan Mekanisme Corporate Governance Terhadap Pengungkapan Tanggung Jawab Sosial Perusahaan Manufaktur Yang Terdaftar di Bursa Efek Indonesia. Jurnal Ekonomi Dan Informasi Akuntansi, 2(40), 31-47.

Tiswiyanti, W., Fitriyani, D., \& Wiralestari. (2012). Analisis Pengaruh Komisaris Independen, Komite Audit Dan Kepemilikan Institusional Terhadap Manajemen Laba. Jurnal Penelitian Universitas Jambi, 14, 56-62.

Triwahyuningtias, M., \& Muharam, H. (2012). Analisis Pengaruh Struktur Kepemilikan, Ukuran Dewan, Komisaris Independen, Likuiditas dan Leverage Terhadap Terjadinya Kondisi Financial Distress (Studi Pada Perusahaan Manufaktur Yang Terdaftar di Bursa Efek Indonesia Tahun 2008-2010). Diponegoro Journal of Accounting Management, 1(1), 1-14.

Ujiyantho, M. A., \& Pramuka, B. A. (2007). Mekanisme Corporate Governance, Manajemen Laba dan Kinerja Keuangan. Simposium Nasional Akuntansi X, 1-26.

Widyastuti, T. (2009). Pengaruh Struktur Kepemilikan dan Kinerja Keuangan Terhadap Manajemen Laba: Studi Pada Perusahaan Manufaktur di BEI. Jurnal MAKSI, 9.

Xie, B., Davidson, W. N., \& Dadalt, P. J. (2003). Earnings Management and Corporate Governance: The Role of The Board and The Audit Committee. Journal of 
Corporate Finance, 9, 295-316.

Yang, W. S., Chun, L. S., \& Ramadili, M. (2009). The Effect of Board Structure and Institutional Ownership Structure on Earnings Management. Journal of Economics and Management, 3(2), 332-353.

Yip, E., Van Staden, C., \& Cahan, S. (2011). Corporate Social Responsibility Reporting and Earnings Management: The Role of Political Costs Corporate Social Responsibility Reporting and Earnings Management: Australasian Accounting Business and Finance Journal, 5(3), 17-34. 